\title{
IL32 Gene
}

National Cancer Institute

\section{Source}

National Cancer Institute. IL32 Gene. NCI Thesaurus. Code C127924.

This gene is involved in cytokine-mediated immunity. 